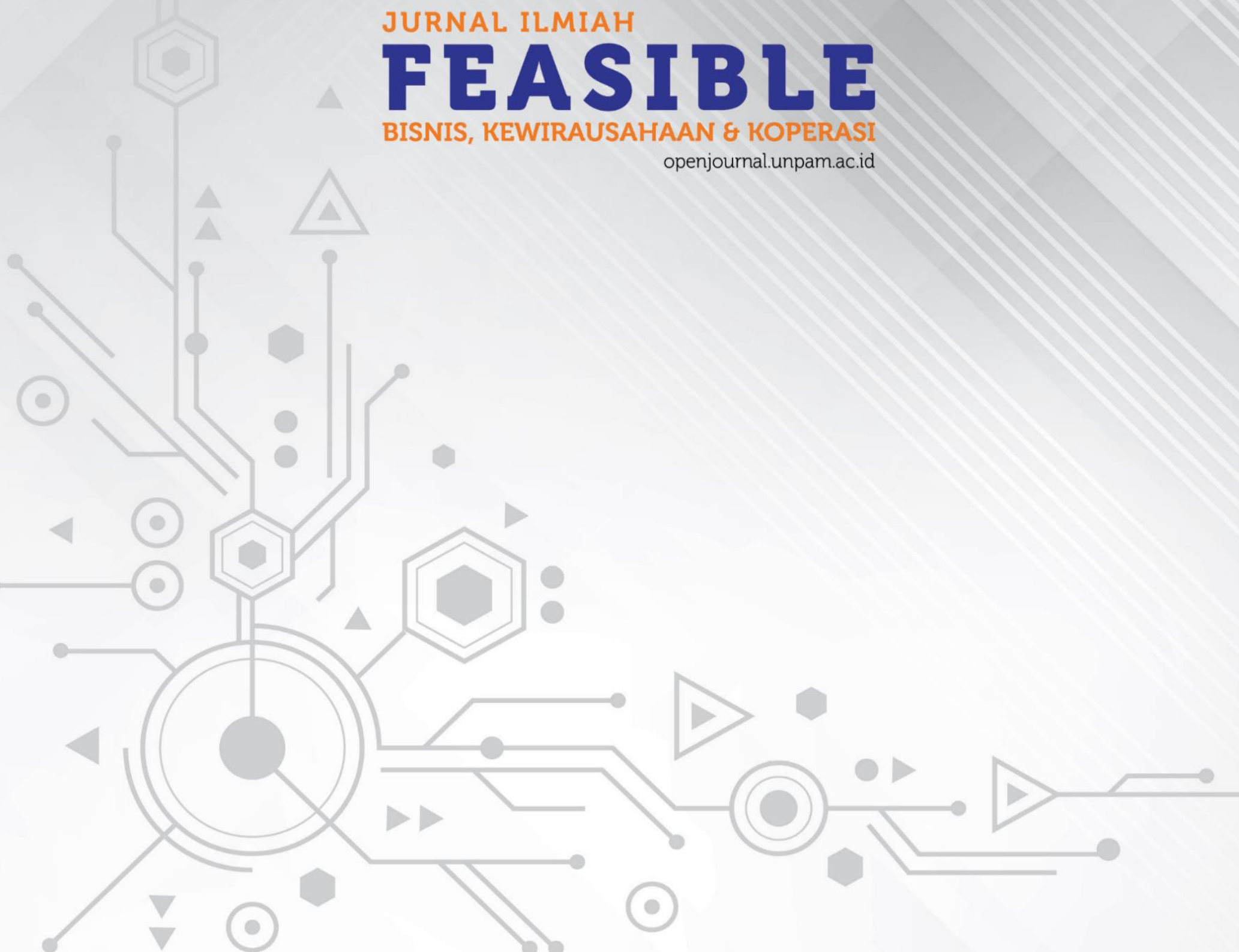




\title{
PENGARUH KUALITAS PELAYANAN DAN LOKASI TERHADAP KEPUASAN PELANGGAN PADA BENGKEL ABADI JAYA MOTOR BOGOR
}

\author{
Ugeng Budi Haryoko; Hapid Rabani \\ Fakultas Ekonomi; Universitas Pamulang \\ ugengbudiunpam@gmail.com
}

\begin{abstract}
Abstrak
Penelitian ini bertujuan untuk mengetahui pengaruh kualitas pelayanan dan lokasi terhadap kepuasan pelanggan pelanggan pada Bengkel Abadi Jaya Motor Bogor. Metode analisis yang digunakan meliputi uji validitas, uji reliabilitas, uji asumsi klasik, uji regresi linear berganda, uji koefisien determinasi, Uji t dan Ujif. Sampel penelitian yaitu konsumen yang konsumen pemakai jasa perbaikan kendaraan motor pada Bengkel Abadi Jaya Motor sebanyak 82 responden. Hasil penelitian ini menunjukkan kualitas pelayanan berpengaruh positif dan signifikan terhadap keputusan pembelian dengan konstribusi sebesar $26,2 \%$. Lokasi berpengaruh positif dan signifikan terhadap kepuasan pelanggan dengan konstribusi sebesar 41,9\%. Secara simultan kualitas pelayanan dan lokasi berpengaruh positif terhadap kepuasan pelanggan dengan persamaan regresi $Y=14,980+O, 230 X_{1}+$ $O, 473 X_{2}$ dan konstribusinya sebesar 46,7\% sedangkan sisanya sebesar 53,3\% dipengaruhi faktor lain. Dari pengujian hipotesis menggunakan uji statistik $F_{\text {hitung }}>F_{\text {tabel }}$ atau $(34,613>$ 2,150) dengan probability o,ooo. Sehingga $H_{o}$ ditolak dan $H_{1}$ diterima. Artinya terdapat pengaruh positif dan signifikan secara simultan antara kualitas pelayanan, dan lokasi terhadap kepuasan pelanggan.
\end{abstract}

Kata Kunci : Kualitas Pelayanan, Lokasi, Kepuasan Pelanggan

\begin{abstract}
This study aims to determine the effect of service quality and location on customer satisfaction of customers at the Workshop of Abadi Jaya Motor Bogor. The analytical methods used include validity test, reliability test, classic assumption test, multiple linear regression test, coefficient of determination test, $t$ test and $f$ test. The research sample is consumers who are consumers of motor vehicle repair services at Abadi Jaya Motor Workshop totaling 82 respondents. The results of this study indicate that service quality has a positive and significant effect on purchasing decisions with a contribution of $26.2 \%$. Location has a positive and significant effect on customer satisfaction with a contribution of 41.9\%. Simultaneously, service quality and location have a positive effect on customer satisfaction with a regression equation $Y=14,980+0,230 X 1+0,473 X 2$ and its contribution is $46.7 \%$ while the remaining $53.3 \%$ is influenced by other factors. From hypothesis testing using statistical tests Fcount> Ftable or $(34.613>2,150)$ with a probability of o,ooo. So Ho is rejected and $\mathrm{H}_{1}$ is accepted. This means that there is a positive and significant effect simultaneously between service quality, and location on customer satisfaction.
\end{abstract}

Keywords: Service Quality, Location, Customer Satisfaction 


\section{PENDAHULUAN}

\section{Latar Belakang}

Pada saat ini banyak sekali kemajuan dan perkembangan yang terjadi dalam dunia otomotif di Indonesia. Dari tahun ke tahun mengalami yang pesat salah satunya di dalam kendaraan roda dua (motor). Kendaraan roda dua (motor) disebut sebagai kendaraan yang "fleksibel" di daratan, karena ditopang dengan bentuknya yang ramping serta dapat menembus kemacetan yang berada pada jalan- jalan tertentu yang memiliki tingkat kemacetan yang tinggi, serta dapat meminimalis waktu tempuh menuju tempat tujuan dibandingkan dengan menaiki transportasi umum lainnya seperti: bus, kereta, busway dan lain sebagainya. Persaingan usaha bengkel motor di kota - kota besar di Indonesia semakin pesat karena merupakan kebutuhan pokok yang harus dipenuhi untuk merawat motor agar nyaman saat digunakan, salah satunya yaitu didaerah Bogor. Bengkel Abadi Jaya Motor merupakan salah satu penyedia jasa pelayanan sevice kerdaraan bermotor yang berada di daerah Bogor, bertujuan memberikan performa kendaraan bermotor menjadi selalu seperti baru dengan service yang memuaskan dan lokasi yang terjangkau bagi para pemilik kendaraan bermotor sehingga tidak perlu khawatir akan kenyamanan dan keamanan dalam berkendaraan.
Tabel 1.1. Data Komplain Bengkel Abadi Jaya Motor Bogor Periode 2015 Sampai 2017

\begin{tabular}{lccc}
\multicolumn{1}{c}{$\begin{array}{c}\text { Jenis komplain } \\
\text { pelanggan }\end{array}$} & 2015 & $\begin{array}{c}\text { Tahun } \\
2016\end{array}$ & 2017 \\
Kelengkapan peralatan & 19 & 24 & 27 \\
bengkel & & & \\
$\begin{array}{l}\text { Kemudahan standar } \\
\text { oprasianal prosedur } \\
\text { pelayanan bengkel }\end{array}$ & 25 & 27 & 17 \\
$\begin{array}{l}\text { Kemampuan bengkel dalam } \\
\text { memberikan pelayanan }\end{array}$ & 39 & 34 & 42 \\
$\begin{array}{l}\text { sesuai dengan yang } \\
\text { dijanjikan }\end{array}$ & & & \\
$\begin{array}{l}\text { Kecepatan kinerja mekanik } \\
\text { dalam memperbaiki motor }\end{array}$ & 23 & 47 & 29 \\
$\begin{array}{l}\text { Lokasi bengkel kurang } \\
\text { strategis }\end{array}$ & 51 & 32 & 21 \\
Jumlah komplain & & & \\
pertahun & $\mathbf{1 5 7}$ & $\mathbf{1 6 4}$ & $\mathbf{1 3 6}$ \\
\hline Sumber:bengkel Abadi Jaya Motor Bogor 2018 & \\
\hline
\end{tabular}

Berdasarkan Tabel 1.1, adanya peningkatan jumlah komplain dari pelanggan dari tahun 2015 sampai 2017 mengenai kelengkapan peralatan bengkel, kemudahan prosedur pelayanan bengkel, kemampuan bengkel dalam memberikan pelayanan sesuai dengan yang dijanjikan, kecepatan kerja mekanik dalam memperbaiki motor, lokasi bengkel kurang strategis setiap tahunnya bertambah, Kenaikan jumlah komplain yang signifikan terdapat pada lokasi bengkel kurang strategis, hal ini dibuktikan dengan meningkatnya jumlah komplain setiap tahunnya. Serta ketidak pastian dari standar oprasional prosedur yang di keluar oleh pihak bengkel yang dilansir terlalu benyak memakan waktu untuk mengerjakan atau didalam perbaikan satu kendaraan. 
Tabel 1.2. Data Jumlah Pengunjung Dan Data Jumlah Transaksi Bengkel Abadi Jaya Motor Bogor Tahun 2015 sampai 2017

\begin{tabular}{cccc} 
Tahun & $\begin{array}{c}\text { Jumlah } \\
\text { Pengunjung } \\
\text { (orang) }\end{array}$ & $\begin{array}{c}\text { Jumlah } \\
\text { Transaksi } \\
\text { (dalam } \\
\text { ribuan) }\end{array}$ & $\begin{array}{c}\text { Presentase } \\
\text { Jumlah }\end{array}$ \\
\hline 2015 & 5.759 & 83.953 & $87,03 \%$ \\
2016 & 5.348 & 71.564 & $83,44 \%$ \\
2017 & 5.103 & 67.723 & $80,64 \%$ \\
\hline
\end{tabular}

Sumber bengkel Abadi Jaya Motor 2018

Dari tabel di atas dapat diketahui pendapatan di bengkel Abadi Jaya Motor mengalami penurunan dari tahun ke tahun. Transaksi pada tahun 2016 mengalami penurunan dengan presentase $83,44 \%$. Dan pada tahun 2017, penurunan kembali terjadi 80,64\% dari tahun 2016. Jadi selama 3 tahun terakhir bengkel Abadi Jya Motor telah mengalami penurunan sebesar $80,66 \%$.

Berdasarkan permasalahan di atas, maka tujuan dalam penelitian ini untuk mengetahui:

1. Pengaruh kualitas pelayanan terhadap kepuasan pelanggan pada bengkel Abadi Jaya Motor.

2. Pengaruh lokasi terhadap kepuasan pelanggan pada bengkel Abadi Jaya Motor.

3. Pengaruh kualitas pelayanan dan lokasi secara bersama-sama terhadap kepuasan pelanggan pada bengkel Abadi Jaya Motor.

\section{Kajian Literatur}

\section{Kualitas Layanan}

Menurut Murdick, et al (dalam Assegaf, 2015:47) "menyatakan bahwa kualitas pelayanan adalah suatu aktivitas ekonomi yang memproduksi atau menghasilkan waktu, tempat, bentuk dan kebutuhan atau keperluan psikologis".

Adapun indikator kualitas jasa (pelayanan), menurut Fandy Tjiptono (2012:43) antara lain meliputi: "1) Bukti fisik (Tangible), berkenaan dengan daya tarik fasilitas fisik, perlengkapan, dan material yang digunakan perusahaan, serta penampilan karyawan; 2) Keandalan (Reliability), berkaitan dengan kemampuan perusahaan untuk memberikan layanan yang akurat sejak pertama kali tanpa membuat kesalahan apapun dan menyampaikan jasanya sesuai dengan waktu yang sisepakati; 3) Daya tanggap (Responsiveness), berkenaan dengan kesediaan dan kemampuan para karyawan untuk membantu para pelanggan dan merespon permintaan mereka, serta menginformasikan kapan jasa akan diberikan dan kemudian memberikan jasa secara cepat; 4) Jaminan (Assurance), berarti pemberian jaminan akan produk yang sesuai ukuran, pelayanan yang tepat dan respon yang akurat; dan 5) Empati (Emphaty), berarti bahwa perusahaan memahami masalah para pelanggannya dan bertindak demi kepentingan pelanggan, serta memberikan perhatian personal kepada para pelanggan."

\section{Lokasi}

"Komponen yang menyangkut lokasi meliputi: pemilihan lokasi yang strategis (mudah dijangkau), di daerah sekitar pusat perbelanjaan, dekat pemukiman penduduk, 
aman dan nyaman bagi pelanggan, adanya fasilitas yang mendukung, seperti adanya lahan parkir, serta faktor-faktor yang lainnya" (Fandi Tjiptono dalam Kuswatiningsih: 2016, 15).

\section{Kepuasan}

"Kepuasan merupakan perasaan seseorang akan kesenangan atau kekecewaan setelah membandingkan kinerja suatu produk yang dirasakan dengan harapan mereka. Jika kinerja tidak memenuhi harapan, pelanggan tidak puas dan jika kinerja sesuai dengan harapan maka pelanggan puas" (Kotler dan Keller: 2012, 138)

Adapun indikator kepuasan pelanggan antara lain meliputi: 1) Dapat memenuhi harapan; 2) Dapat memenuhi kebutuhan; 3) Menceritakan hal-hal yang baik dan bersedia untuk merekomendasikan; 4) Kurang memperhatikan merek dan iklan produk pesaing; dan 5) Menawarkan ide produk atau jasa kepada perusahaan.

\section{Kerangka Pemikiran}

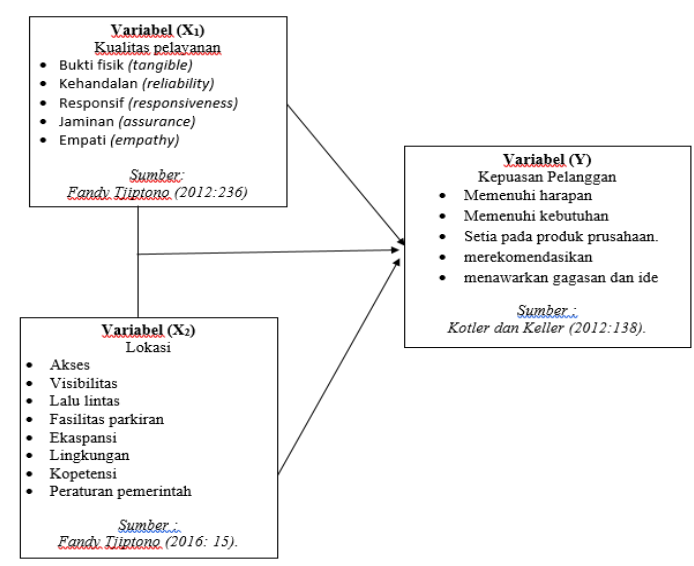

Gambar 1.1 Kerangka Pemikiran

\section{METODE}

Metode analisis yang digunakan dalam penelitian yaitu penelitian deskriptif kualitatis dengan mengunakan uji analisis validitas, reliabilitas, uji asumsi klasik, uji regresi linear berganda, uji koefisien determinasi, uji t dan uji F. Populasi dalam penelitian ini adalah konsumen yang konsumen yang memakai jasa perbaikan kendaraan motor pada Bengkel Abadi Jaya Motor sebanyak 457 konsumen. Sedangkan jumlah sampel menggunakan rumus slovin sebanyak 82 responden.

\section{HASIL dan PEMBAHASAN}

\section{Uji Validitas Kualitas Pelayanan}

Tabel 1.3. Pengujian Validitas Instrumen

Pertanyaan Kualitas Pelayanan $\left(X_{1}\right)$

\begin{tabular}{|l|c|c|c|}
\hline \multicolumn{1}{|c|}{ Pernyataan } & $\mathrm{r}$ hitung & $\mathrm{r}$ tabel & Keputusan \\
\hline $\begin{array}{l}\text { 1. Penampilan karyawan } \\
\text { sopan }\end{array}$ & 0,439 & 0,181 & Valid \\
\hline $\begin{array}{l}\text { 2. } \text { Peralatan penunjang } \\
\text { lengkap }\end{array}$ & 0,647 & 0,181 & Valid \\
\hline $\begin{array}{l}\text { 3. } \text { Area bengkel yang } \\
\text { bersih }\end{array}$ & 0,349 & 0,181 & Valid \\
\hline $\begin{array}{l}\text { 4. Pelayanan petugas } \\
\text { selalu baik }\end{array}$ & 0,329 & 0,181 & Valid \\
\hline $\begin{array}{l}\text { 5. Tidak mengelabuhi } \\
\text { pelanggan }\end{array}$ & 0,407 & 0,181 & Valid \\
\hline $\begin{array}{l}\text { 6. Ketepatan informasi } \\
\text { 7. Ketanggapan } \\
\text { pelayanan }\end{array}$ & 0,388 & 0,181 & Valid \\
\hline 8. Kecepatan merespon & 0,520 & 0,181 & Valid \\
\hline $\begin{array}{l}\text { 9. Pelayanan tepat } \\
\text { waktu }\end{array}$ & 0,407 & 0,181 & Valid \\
\hline $\begin{array}{l}\text { 10.Jaminan produk } \\
\text { sesuai ukuran }\end{array}$ & 0,622 & 0,181 & Valid \\
\hline $\begin{array}{l}\text { 11. Petugas mudah } \\
\text { mengerti }\end{array}$ & 0,454 & 0,181 & Valid \\
\hline $\begin{array}{l}\text { 12. Memberikan } \\
\text { perhatian }\end{array}$ & 0,625 & 0,181 & Valid \\
\hline
\end{tabular}

Dari data tabel di atas, seluruh item instrumen kualitas pelayanan $\left(\mathrm{X}_{1}\right)$ dikatakan valid karena nilai $r_{\text {hitung }}>r_{\text {tabel }}$. 


\section{Uji Validitas Lokasi}

Tabel 1.4. Pengujian Validitas Instrumen Pertanyaan Lokasi (X2)

\begin{tabular}{|l|c|c|c|}
\hline \multicolumn{1}{|c|}{ Pernyataan } & $\mathrm{r}$ hitung & $\mathrm{r}$ tabel & Keputusan \\
\hline 1. Lokasi yang strategis & 0,451 & 0,181 & Valid \\
\hline $\begin{array}{l}\text { 2. } \text { Berdekatan } \\
\text { transportasi umum }\end{array}$ & 0,539 & 0,181 & Valid \\
\hline $\begin{array}{l}\text { 3. Lokasi dekat dengan } \\
\text { pusat keramaian }\end{array}$ & 0,519 & 0,181 & Valid \\
\hline $\begin{array}{l}\text { 4. Memudahkan minat } \\
\text { pelanggan }\end{array}$ & 0,612 & 0,181 & Valid \\
\hline $\begin{array}{l}\text { 5. Memudahkan } \\
\text { pembelian secara } \\
\text { spontan }\end{array}$ & 0,305 & 0,181 & Valid \\
\hline $\begin{array}{l}\text { 6. Dampak kemacetan } \\
\text { dalam pelayanan }\end{array}$ & 0,537 & 0,181 & Valid \\
\hline $\begin{array}{l}\text { 7. Lokasi parkir yang } \\
\text { luas }\end{array}$ & 0,381 & 0,181 & Valid \\
\hline $\begin{array}{l}\text { 8. Keamanan dan } \\
\text { kenyamanan }\end{array}$ & 0,615 & 0,181 & Valid \\
\hline $\begin{array}{l}\text { 9. Ketersedian lahan } \\
\text { yang cukup }\end{array}$ & 0,615 & 0,181 & Valid \\
\hline $\begin{array}{l}\text { 10.Mendukung minat } \\
\text { pelanggan }\end{array}$ & 0,502 & 0,181 & Valid \\
\hline $\begin{array}{l}\text { 11. Lokasi dengan } \\
\text { kompetitor cukup } \\
\text { jauh }\end{array}$ & 0,311 & 0,181 & Valid \\
\hline $\begin{array}{l}\text { 12. Mendapatkan ijin } \\
\text { usaha }\end{array}$ & 0,181 & Valid \\
\hline
\end{tabular}

Sumber : Hasil Pengolahan Data, 2018.

Dari data tabel di atas, seluruh item instrumen lokasi $\left(\mathrm{X}_{2}\right)$ dikatakan valid karena nilai $\mathrm{r}_{\text {hitung }}>\mathrm{r}_{\text {tabel }}$.

\section{Uji Validitas Kepuasan Pelanggan}

Tabel 1.5. Pengujian Validitas Instrumen Pertanyaan Kepusan Pelanggan (Y)

\begin{tabular}{|c|c|c|c|}
\hline Pernyataan & $\mathrm{r}$ hitung & $\mathrm{r}$ tabel & Keputusan \\
\hline $\begin{array}{l}\text { Dapat memenuhi } \\
\text { keinginan }\end{array}$ & 0,349 & 0,181 & Valid \\
\hline $\begin{array}{ll}\text { 2. } & \text { Memberikan rasa } \\
\text { nyaman }\end{array}$ & 0,654 & 0,181 & Valid \\
\hline $\begin{array}{l}\text { 3. } \\
\text { Memprioritaskan } \\
\text { permintaan }\end{array}$ & 0,236 & 0,181 & Valid \\
\hline $\begin{array}{l}\text { 4. Dapat memenuhi } \\
\text { kebutuhan }\end{array}$ & 0,672 & 0,181 & Valid \\
\hline $\begin{array}{ll}\text { 5. } & \text { Ketepatan } \\
\text { pengadaan barang }\end{array}$ & 0,562 & 0,181 & Valid \\
\hline $\begin{array}{l}\text { Ketepatan rencana } \\
\text { produksi }\end{array}$ & 0,425 & 0,181 & Valid \\
\hline $\begin{array}{l}\text { 7. Tidak berniat } \\
\text { membeli yang lain }\end{array}$ & 0,548 & 0,181 & Valid \\
\hline 8. Susah tergantikan & 0,372 & 0,181 & Valid \\
\hline $\begin{array}{ll}9 . & \text { Senang melakukan } \\
\text { kerjasama }\end{array}$ & 0,247 & 0,181 & Valid \\
\hline $\begin{array}{l}\text { 10. Merekomendasikan } \\
\text { ke orang lain }\end{array}$ & 0404 & 0,181 & Valid \\
\hline $\begin{array}{l}\text { 11. Memberikan } \\
\text { masukan }\end{array}$ & 0,559 & 0,181 & Valid \\
\hline $\begin{array}{l}\text { 12. Mendorong inovasi } \\
\text { pelayanan }\end{array}$ & 0,382 & 0,181 & Valid \\
\hline
\end{tabular}

Sumber : Hasil Pengolahan Data, 2018.
Dari data tabel di atas, seluruh item instrumen variabel kepuasan pelanggan (Y) dikatakan valid karena diperoleh nilai $\mathbf{r}_{\text {hitung }}$ $>\mathrm{r}_{\text {tabel }}$

\section{Uji Reliabilitas}

Hasil uji reliabilitas, butir pernyataan dikatakan dikatakan reliabel apabila nilai $r_{\text {hitung }}$ lebih besar $r_{\text {tabel }}(0,181)$. Hasil uji reliabilitas seperti ditunjukkan pada tabel berikut:

\begin{tabular}{lccc}
\multicolumn{4}{c}{$\begin{array}{c}\text { Tabel 1.6. Hasil Pengujian Reliabilitas Variabel } \\
\text { Independen dan Variabel Dependen }\end{array}$} \\
\begin{tabular}{l}
\multicolumn{1}{c}{ Variabel } \\
r hitung
\end{tabular} & $\mathrm{r}$ tabel & Keputusan \\
$\begin{array}{l}\text { Kualitas Pelayanan } \\
\text { (X1) }\end{array}$ & 0,708 & 0,181 & Reliabel \\
$\begin{array}{l}\text { Lokasi (X2) } \\
\text { Kepuasan }\end{array}$ & 0,714 & 0,181 & Reliabel \\
Pelanggan & 0,704 & 0,181 & Reliabel \\
\hline
\end{tabular}

Sumber : Hasil Pengolahan Data, 2018.

Hasil perhitungan reliabilitas menunjukkan bahwa semua item dinyatakan reliabel nilai $\mathrm{r}_{\text {hitung }}$ lebih besar dari nilai $r_{\text {tabel }}(0,181)$.

\section{Uji Asumsi Klasik}

\section{Uji Normalitas}

Uji Normalitas dilakukan dengan melihat grafik P-P Plot sebagai berikut:

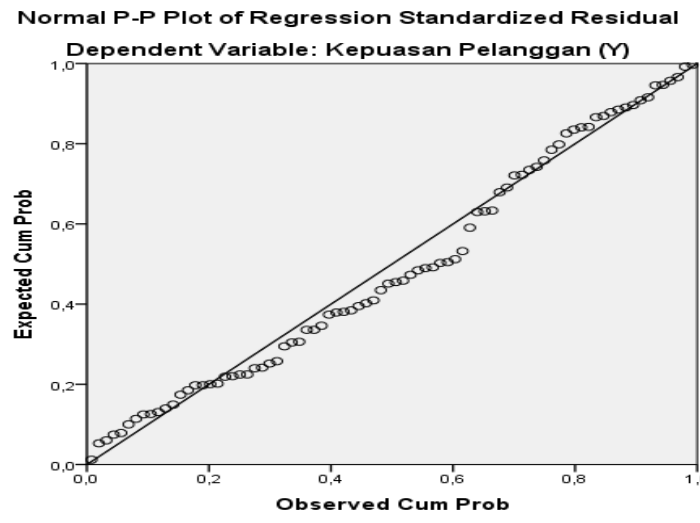

Gambar 1.2 P-P Plot Uji Normalitas Diagram Penyebaran Titik Residual 
Dari gambar dapat diketahui bahwa pola grafiknya normal, karena penyebarannya berada pada garis normal dan mengikuti garis diagonal. Artinya data terdistribusi normal.

\section{Uji Multikolinearitas}

Data penelitian dikatakan tidak mengalami multikolinieritas apabila nilai Tolerance Value kurang dari 1 dan nilai Variance Inflation Factor (VIF) kurang dari 10.

Tabel 1.7. Hasil Pengujian Multikolinearitas Dengan Collinearity Statistic

Coefficients $^{\mathrm{a}}$

\begin{tabular}{|l|r|r|}
\hline \multirow{2}{*}{ Model } & \multicolumn{2}{|c|}{ Collinearity Statistics } \\
\cline { 2 - 3 } & Tolerance & \multicolumn{1}{c|}{ VIF } \\
\hline \multirow{3}{*}{$\begin{array}{l}\text { (Constant) } \\
\text { Kualitas Pelanggan (X1) }\end{array}$} & & \\
\cline { 2 - 3 } Lokasi (X2) &, 751 & 1,331 \\
\cline { 2 - 3 } &, 751 & 1,331 \\
\hline
\end{tabular}

a. Dependent Variable: Kepuasan Pelanggan (Y)

Sumber : Hasil Pengolahan Data, 2018

Hasil uji multikolinieritas diperoleh nilai toleransi $<1$ dan nilai VIF $<10$, berarti model regresi tidak mengalami multikolinearitas.

\section{Uji Heteroskedastisitas}

Uji heteroskedastisitas digunakan untuk menguji apakah dalam sebuah model regresi terjadi ketidaksamaan varians residual. Model regresi dikatakan mengalami heteroskedastisitas apabila pada grafik scatter plot apabila titik-titik membentuk pola tertentu seperti gelombang besar melebar dan menyempit.

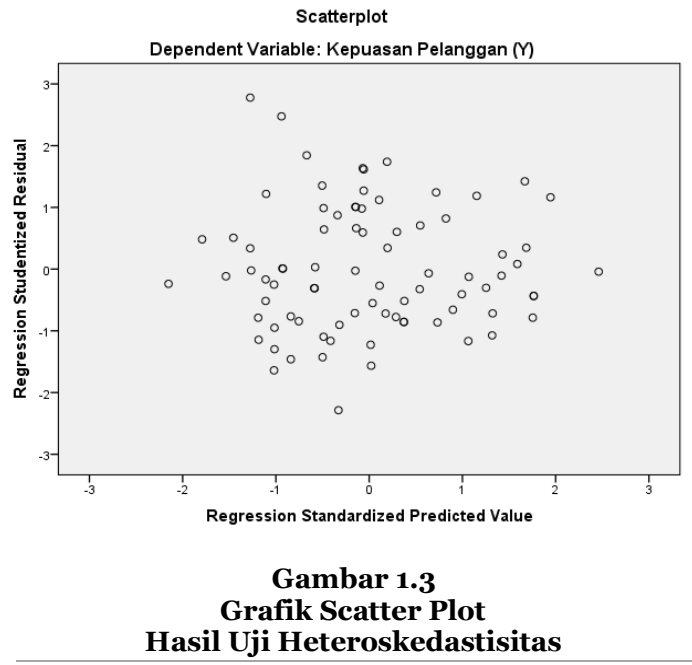

Dari grafik, titik-titik pada grafik scatterplot menunjukkan tidak terdapat gangguan heteroskedatisitas pada model, karena titik-titik penyebaran tidak membentuk polapola tertentu dan menyebar di atas dan di bawah angka o pada sumbu Y.

\section{Analisis Data Deskriptif}

\section{a. Deskripsi Variabel Kualitas Pelayanan $\left(\mathrm{X}_{1}\right)$}

Tabel 1.10. Jawaban Responden Berdasar Pada Butir Pertanyaan

Variabel Kualitas Pelayanan $\left(X_{1}\right)$

\begin{tabular}{|c|c|c|c|c|c|c|c|c|}
\hline Pertanyaan & $\frac{\text { STS }}{1}$ & $\begin{array}{c}\mathrm{TS} \\
2\end{array}$ & $\begin{array}{c}\mathrm{KS} \\
\mathbf{3}\end{array}$ & $\begin{array}{l}5 \\
4\end{array}$ & $\frac{\mathrm{SS}}{5}$ & Total & $\begin{array}{l}\text { Rata2 } \\
\text { Seor }\end{array}$ & Kriteria \\
\hline $\begin{array}{l}\text { 1. Penampilan } \\
\text { karyawan sopan }\end{array}$ & 0 & 1 & 22 & 33 & 26 & $\underline{82}$ & 4,02 & Baik \\
\hline $\begin{array}{l}\text { 2. Peralatan } \\
\text { penunjang } \\
\text { lengkap }\end{array}$ & 0 & 4 & 24 & 40 & 14 & $\underline{82}$ & 3,78 & Baik \\
\hline $\begin{array}{l}\text { 3. Area bengkel } \\
\text { yang bersih }\end{array}$ & 0 & 7 & 23 & 42 & 10 & $\underline{82}$ & 3,67 & Baik \\
\hline $\begin{array}{l}\text { 4. Pelayanan } \\
\text { petugas sclalu } \\
\text { baik }\end{array}$ & 0 & 7 & 27 & 41 & 7 & $\underline{82}$ & 3,59 & Baik \\
\hline $\begin{array}{l}\text { 5. Tidak } \\
\text { mengelabuhi } \\
\text { pelanggan }\end{array}$ & 0 & 4 & 25 & 43 & 10 & $\underline{82}$ & 3,72 & Baik \\
\hline $\begin{array}{l}\text { 6. Ketepatan } \\
\text { informasi }\end{array}$ & 0 & 5 & 31 & 31 & 15 & $\underline{82}$ & 3,68 & Baik \\
\hline 7. Ketanggapan & 0 & 5 & 32 & 37 & 8 & $\underline{82}$ & 3,59 & Baik \\
\hline $\begin{array}{l}\text { 8. Kecepatan } \\
\text { merespon }\end{array}$ & 0 & 4 & 19 & 29 & 30 & $\underline{82}$ & 4,04 & Baik \\
\hline $\begin{array}{l}\text { 9. Pelayanan tepat } \\
\text { waktu }\end{array}$ & 0 & 2 & 30 & 41 & 9 & $\underline{82}$ & 3,70 & Baik \\
\hline $\begin{array}{l}\text { 10. Jaminan produk } \\
\text { sesuai ukuran }\end{array}$ & 0 & 1 & 39 & 30 & 12 & $\underline{82}$ & 3,65 & Baik \\
\hline $\begin{array}{l}\text { 1. Petugas mudah } \\
\text { mengerti }\end{array}$ & 0 & 2 & 12 & 44 & 24 & $\underline{82}$ & 4,10 & Baik \\
\hline $\begin{array}{l}\text { 12. Memberikan } \\
\text { perhatian }\end{array}$ & 0 & 3 & 21 & 46 & 12 & $\underline{82}$ & 3,82 & Baik \\
\hline Jumlah & 0 & 45 & 305 & 457 & 177 & 984 & Rat & - Rata \\
\hline Presentase jawaban & $0,00 \%$ & $4,57 \%$ & $31,00 \%$ & $46,44 \%$ & $17,99 \%$ & $100,0 \%$ & 3,78 & Baik \\
\hline
\end{tabular}

Berdasarkan tabel di atas, tanggapan responden terhadap variabel kualitas pelayanan $\left(\mathrm{X}_{1}\right)$ memiliki kategori skala tinggi atau baik, dilihat dari skor tertinggi 
4,10 yaitu pada pernyataan "petugas mudah dimengerti” sehingga banyak responden yang memilih menggunakan jasa yang ditawarkan oleh Bengkel Abadi Jaya Motor. Sedangkan angka terendah yaitu pada pernyataan " pelayanan petugas selalu baik" dengan bobot 3,59 karenanya perusahaan perlu meningkatkan kualitas pelayanan lebih baik lagi, diantaraya dengan menerapkan sistem $3 \mathrm{~S}$ (senyum,salam dan sapa) bagi layanan seluruh karyawan.

\section{b. Deskripsi Variabel Lokasi $\left(\mathrm{X}_{2}\right)$}

Tabel 1.11. Jawaban Responden Berdasar Pada Butir Pertanyaan Variabel Lokasi $\left(\mathrm{X}_{2}\right)$

\begin{tabular}{|c|c|c|c|c|c|c|c|c|}
\hline Pertanyaan & $\frac{\text { STS }}{1}$ & $\frac{\mathrm{TS}}{2}$ & $\frac{\mathrm{KS}}{3}$ & $\frac{S}{4}$ & $\frac{\mathrm{SS}}{5}$ & Total & $\begin{array}{l}\text { Rata2 } \\
\text { Scor }\end{array}$ & Kriteria \\
\hline 1. Lokasi yang & 0 & 3 & 22 & 40 & 17 & $\underline{82}$ & 3,87 & Baik \\
\hline $\begin{array}{l}\text { 2. Berdekatan } \\
\text { transpottasi } \\
\text { umum }\end{array}$ & 0 & 2 & 42 & 24 & 14 & $\underline{82}$ & 3,61 & Baik \\
\hline $\begin{array}{l}\text { 3. Lokasi dekat } \\
\text { dengan pusat } \\
\text { keramaian }\end{array}$ & 0 & 3 & 27 & 39 & 13 & $\underline{82}$ & 3,76 & Baik \\
\hline $\begin{array}{l}\text { 4. Memudahkan } \\
\text { minat pelanggan }\end{array}$ & 0 & 4 & 24 & 34 & 20 & $\underline{82}$ & 3,85 & Baik \\
\hline $\begin{array}{l}\text { 5. Memudahkan } \\
\text { pembelian secara } \\
\text { spontan }\end{array}$ & 0 & 1 & 25 & 38 & 18 & $\underline{82}$ & 3,89 & Baik \\
\hline $\begin{array}{l}\text { 6. Dampak } \\
\text { kemacetan dalam } \\
\text { pelayanan }\end{array}$ & 0 & 1 & 28 & 39 & 14 & $\underline{82}$ & 3,80 & Baik \\
\hline $\begin{array}{l}\text { 7. Lokasi parkir } \\
\text { yang jauh dari } \\
\text { bengkel }\end{array}$ & 0 & 1 & 18 & 45 & 18 & $\underline{82}$ & 983, & Baik. \\
\hline $\begin{array}{l}\text { 8. Keamanan dan } \\
\text { kenvamanan }\end{array}$ & 0 & 1 & 25 & 36 & 20 & $\underline{82}$ & 3,91 & Baik \\
\hline 9. Ketersedian lahan & 0 & 1 & 25 & 36 & 20 & $\underline{82}$ & 3,91 & Baik \\
\hline $\begin{array}{l}\text { 10. Mendukung } \\
\text { minat pelanggan }\end{array}$ & 0 & 3 & 31 & 33 & 15 & $\underline{82}$ & 3,73 & Baik \\
\hline $\begin{array}{l}\text { 11. Lokasi dengan } \\
\text { kompetitor culup } \\
\text { jauh }\end{array}$ & 0 & 1 & 19 & 39 & 23 & $\underline{82}$ & 4,02 & Baik \\
\hline $\begin{array}{l}\text { 12. Mendapatkan ijin } \\
\text { usaha }\end{array}$ & 0 & 0 & 15 & 42 & 25 & $\underline{82}$ & 4,12 & Baik \\
\hline Jumlah & 0 & 21 & 301 & $\frac{445}{4520 \%}$ & 217 & 984 & Rate & - Rata \\
\hline
\end{tabular}

Dari tabel di atas, tanggapan responden terhadap variabel lokasi $\left(\mathrm{X}_{2}\right)$ memiliki kategori skala tinggi atau baik, dengan skor tertinggi 4,12 pada pernyataan "medapatkan ijin usaha" sehingga banyak responden yang memilih untuk menggunakan jasa dari Bengkel Abadi Jaya Motor karena keberadaan jasa bengkel yang digunakan telah mendapakan surat edaran prihal ijin usaha dari pemerintah setempat. Sedangkan angka terendah yaitu pada pernyataan "berdekatan dengan transport- tasi umum" dengan skor 3,61. Karenanya perusahaan perlu memberikan kenyamanan bagi masyarakat dengan cara memberikan fasilitas tempat parkir yang dekat dengan lokasi bengkel sehingga memberikan rasa aman bagi masyarakat yang menggunakan jasa.

\section{c. Deskripsi Variabel Kepuasan Pelanggan (Y)}

Tabel 1.12. Jawaban Responden Berdasar Pada Butir Pertanyaan

Variabel Kepuasan Pelanggan (Y)

\begin{tabular}{|c|c|c|c|c|c|c|c|c|}
\hline Pertanyaan & $\frac{\text { STS }}{1}$ & $\frac{\text { TS }}{2}$ & $\frac{\mathrm{KS}}{3}$ & $\begin{array}{l}S \\
4\end{array}$ & $\frac{S S}{5}$ & Total & $\begin{array}{c}\text { Rata2 } \\
\text { Scor }\end{array}$ & Kriteria \\
\hline $\begin{array}{l}\text { 1. Dapat memenuhi } \\
\text { keinginan }\end{array}$ & o & o & 24 & 50 & 8 & 82 & 3,80 & Baik \\
\hline $\begin{array}{l}\text { 2. Memberikan rasa } \\
\text { nvaman }\end{array}$ & o & 1 & 22 & 37 & 22 & 82 & 3,98 & Baik \\
\hline $\begin{array}{l}\text { 3. Memprioritaskan } \\
\text { permintaan }\end{array}$ & o & 1 & $3^{36}$ & $3^{1}$ & 14 & 82 & 3,71 & Baik \\
\hline $\begin{array}{l}\text { 4. Dapat memenuhi } \\
\text { kebutuhan }\end{array}$ & o & 1 & 15 & 37 & 29 & 82 & 4,15 & Baik \\
\hline $\begin{array}{l}\text { 5. Ketepatan } \\
\text { pengadaan barang }\end{array}$ & o & 1 & $3^{1}$ & 35 & 15 & 82 & 3,78 & Baik \\
\hline $\begin{array}{l}\text { 6. Ketepatan rencana } \\
\text { produlssi }\end{array}$ & o & o & 19 & 44 & 19 & 82 & 4,00 & Baik \\
\hline $\begin{array}{l}\text { 7. Tidakk berniat } \\
\text { membeli vang lain }\end{array}$ & o & 2 & 16 & $3^{8}$ & 26 & 82 & 4,07 & Baik \\
\hline 8. Susah tergantikan & o & o & 27 & 39 & 16 & 82 & 3,87 & Baik \\
\hline $\begin{array}{l}\text { 9. Senang melakukan } \\
\text { keriasama }\end{array}$ & o & $\circ$ & 24 & 45 & 13 & 82 & 3,87 & Baik \\
\hline $\begin{array}{l}\text { 10. Merekomendasikan } \\
\text { ke orang lain }\end{array}$ & o & o & 14 & 46 & 22 & 82 & 4,10 & Baik \\
\hline $\begin{array}{l}\text { 11. Memberikkan } \\
\text { masukan }\end{array}$ & o & o & 21 & 35 & 26 & 82 & 4,06 & Baik \\
\hline $\begin{array}{l}\text { 12. Mendorong inovasi } \\
\text { pelayanan }\end{array}$ & o & o & 19 & 36 & 27 & 82 & 4,10 & Baik \\
\hline \begin{tabular}{|c|} 
Jumlah \\
Presentase jawaban
\end{tabular} & 0 & 6 & $\begin{array}{l}268 \\
27.24 \%\end{array}$ & $\frac{473}{48,07 \%}$ & $\begin{array}{l}237 \\
2409 \%\end{array}$ & $\frac{984}{100,0 \%}$ & $\frac{\mathrm{Ra}}{2.97}$ & $\frac{a-\text { Rata }}{\text { Baik }}$ \\
\hline
\end{tabular}

Tanggapan responden terhadap kepuasan pelanggan (Y) memiliki kategori tinggi atau baik, dengan skor tertinggi 4,15 pada pernyataan "memenuhi kebutuhan" sehingga banyak responden yang memilih untuk memberikan saran atau masuk kepada pihak perusahaan perihal jasa dari Bengkel Abadi Jaya Motor agar bisa lebih berkembang. Sedangkan skor terendah pada pernyataan "memprioritaskan permintaan" dengan skor 3,71\%. Karenanya perusahaan perlu memberikan kenyamanan bagi masyarakat dengan cara memberikan barang-barang yang berkualitas untuk kenyamanan masyarakat dalam melakukan aktivitas dengan kendaraan bermotor, 
sehingga memberikan rasa aman bagi masyarakat yang menggunakan jasa.

\section{Analisis Verifikatif}

\section{a. Analisis Regresi Linier Berganda}

\begin{tabular}{|c|c|c|c|c|c|}
\hline \multicolumn{6}{|c|}{$\begin{array}{c}\text { Tabel } 1.13 \\
\text { Hasil Pengolahan Regresi Berganda Variabel } \\
\text { Kualitas Pelayanan }\left(X_{1}\right) \\
\text { dan Lokasi }\left(X_{2}\right)\end{array}$} \\
\hline \multirow{2}{*}{ Model } & \multicolumn{2}{|c|}{$\begin{array}{l}\text { Unstandardized } \\
\text { Coefficients }\end{array}$} & \multirow{2}{*}{$\begin{array}{c}\begin{array}{c}\text { Standardized } \\
\text { Coefficients }\end{array} \\
\text { Beta }\end{array}$} & \multirow{2}{*}{$t$} & \multirow{2}{*}{ Sig. } \\
\hline & B & $\begin{array}{l}\text { Std. } \\
\text { Error }\end{array}$ & & & \\
\hline (Constant) & 14,980 & 3,983 & & 3,761 & ,000 \\
\hline$\frac{\text { Kualitas Pelayanan }}{(\mathrm{X} 1)}$ & ,230 & ,086 &, 252 & 2,656 & ,010 \\
\hline Lokasi (X2) & ,473 & , 086 &, 522 & 5,508 & , 000 \\
\hline
\end{tabular}

a. Dependent Variable: Kepuasan Pelanggan (Y)

Hasil perhitungan regresi diperoleh persamaan regresi $\mathrm{Y}=14,980+0,230 \mathrm{X}_{1}+$ $0,473 X_{2}$.

a. Nilai konstanta 14,98 berarti jika kualitas layanan dan lokasi tidak ada kepuasan pelanggan sudah memiliki nilai 14,98 .

b. Nilai 0,230 pada variabel kualitas pelayanan artinya jika ada kenaikan satu tingkat kualitas pelayanan maka kepuasan pelanggan akan meningkat sebesar 0,230 point. Demikian pula jika ada penurunan satu tingkat kualitas pelayanan maka kepuasan pelanggan juga menurun o,230 point.

c. Nilai 0,473 pada variabel lokasi artinya jika ada kenaikan satu tingkat lokasi maka kepuasan pelanggan akan meningkat sebesar o,473 point. Demikian pula jika ada penurunan satu tingkat lokasi maka kepuasan pelanggan juga menurun 0,473 point.

\section{b. Pengaruh Secara Parsial.}

Tabel 1.14. Pengaruh Kualitas Pelayanan $\left(X_{1}\right)$ Terhadap Kepuasan Pelanggan (Y)

Model Summary ${ }^{b}$

\begin{tabular}{l|c|r|r|r|}
\hline Model & $\mathrm{R}$ & $\begin{array}{c}\mathrm{R} \\
\text { Square }\end{array}$ & $\begin{array}{c}\text { Adjusted R } \\
\text { Square }\end{array}$ & $\begin{array}{c}\text { Std. Error of } \\
\text { the Estimate }\end{array}$ \\
\hline 1 &, $512^{\mathrm{a}}$ &, 262 &, 253 & 3,412 \\
\hline
\end{tabular}
a. Predictors: (Constant), Kualitas Pelayanan (X1)
b. Dependent Variable: Kepuasan Pelanggan (Y)

Nilai $R$ sebesar 0,512 menunjukkan korelasi cukup kuat sedangkan nilai $R$ square sebesar 0,262 menunjukkan konstribusi kualitas pelayanan terhadap kepuasan pelanggan sebesar 26,2\%.

\begin{tabular}{|c|c|c|c|c|}
\hline \multicolumn{5}{|c|}{$\begin{array}{c}\text { Tabel 1.15. Pengaruh Secara Parsial Variabel } \\
\text { Lokasi }\left(X_{2}\right) \\
\text { Terhadap Kepuasan Pelanggan (Y) } \\
\text { Model Summaryb }\end{array}$} \\
\hline Model & $\mathrm{R}$ & R Square & $\begin{array}{l}\text { Adjusted R } \\
\text { Square }\end{array}$ & $\begin{array}{l}\text { Std. Error of the } \\
\text { Estimate }\end{array}$ \\
\hline 1 & ,648 & ,419 & ,412 & 3,027 \\
\hline
\end{tabular}

b. Dependent Variable: Kepuasan Pelanggan $(\mathrm{Y})$

Nilai $R$ sebesar 0,648 menunjukkan korelasi kuat sedangkan nilai $R$-square sebesar 0,262 menunjukkan konstribusi lokasi terhadap kepuasan pelanggan sebesar $41,9 \%$.

\section{c. Koefisien Determinasi}

\begin{tabular}{l}
\hline $\begin{array}{r}\text { Tabel 1.16. Hasil Pengolahan Data } \\
\text { Koefisien Determinasi } \\
\text { Model Summary }\end{array}$ \\
\begin{tabular}{|l|r|r|r|r}
\hline & & $\mathrm{R}$ & Adjusted \\
Model & $\mathrm{R}$ & $\begin{array}{c}\text { Square } \\
\text { R Square }\end{array}$ & $\begin{array}{c}\text { Std. Error of the } \\
\text { Estimate }\end{array}$ \\
\hline 1 &, $683^{\mathrm{a}}$ &, 467 &, 454 & 2,918 \\
\hline a. Predictors: (Constant), Lokasi $\left(\mathrm{X}_{2}\right)$, Kualitas Pelanggan $\left(\mathrm{X}_{1}\right)$
\end{tabular} \\
b. Dependent Variable: Kepuasan Pelanggan (Y) \\
Nilai $R$ sebesar o,683 menunjuk-kan \\
korelasi kuat dan nilai $R$-square sebesar \\
O,467 menunjukkan besarnya konstribusi \\
kualitas pelayanan dan lokasi terhadap \\
kepuasan pelanggan pada Bengkel Abadi
\end{tabular}


Jaya Motor Bogor sebesar 46,7\% sedangkan sisanya 53,3\% dipengaruhi oleh faktor lain.

\section{d. Pengujian Hipotesis}

\section{1) Pengaruh Kualitas Pelayanan} terhadap Kepuasan Pelanggan

\begin{tabular}{|c|c|c|c|c|c|}
\hline \multicolumn{6}{|c|}{$\begin{array}{c}\text { Tabel 1.17. Hasil Uji t } \\
\text { Variabel Kepuasan Pelanggan } \\
\text { Coefficients }^{\text {a }}\end{array}$} \\
\hline & \multicolumn{2}{|c|}{$\begin{array}{c}\text { Unstandardized } \\
\text { Coefficients }\end{array}$} & \multirow{2}{*}{$\begin{array}{c}\begin{array}{r}\text { Standardized } \\
\text { Coefficients }\end{array} \\
\text { Beta }\end{array}$} & \multirow[b]{2}{*}{$\mathrm{t}$} & \multirow{2}{*}{ Sig. } \\
\hline & B & $\begin{array}{l}\text { Std. } \\
\text { Error }\end{array}$ & & & \\
\hline 1 (Constant) & 26,286 & 3,990 & & 6,587 & ,000 \\
\hline $\begin{array}{l}\text { Pelanggan } \\
\left(\mathrm{X}_{1}\right)\end{array}$ & ,467 & ,088 &, 512 & 5,334 & ,000 \\
\hline
\end{tabular}

a. Dependent Variable: Kepuasan Pelanggan (Y)

Dari tabel diperoleh nilai $t_{\text {hitung }}>t_{\text {tabel }}$ $(5,334>1,663)$ dengan nilai signifikansi o,ooo, sehingga $\mathrm{H}_{\mathrm{o}}$ ditolak dan $\mathrm{H}_{1}$ diterima, artinya terdapat pengaruh yang positif dan signifikan kualitas pelayanan terhadap kepuasan pelanggan pada Bengkel Abadi Jaya Motor.

\section{2) Pengaruh Kualitas Pelayanan}

\section{terhadap Kepuasan Pelanggan}

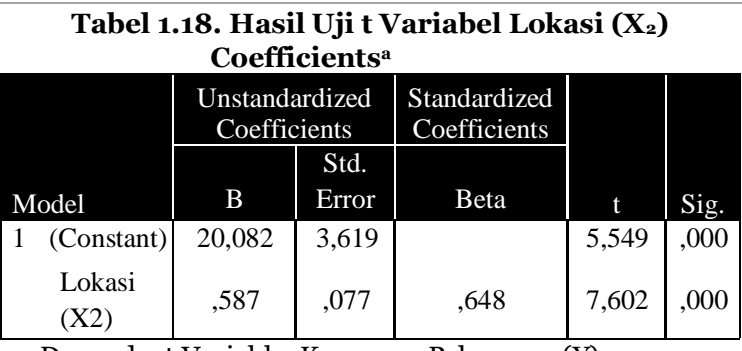

a. Dependent Variable: Kepuasan Pelanggan (Y)

Dari tabel diperoleh nilai $t_{\text {hitung }}>t_{\text {tabel }}$ (7.602 > 1,663), dan nilai signifikansi 0,000 sehingga $\mathrm{H}_{\mathrm{o}}$ ditolak dan $\mathrm{H}_{1}$ diterima, artinya terdapat pengaruh yang positif dan signifikan antara lokasi terhadap kepuasan pelanggan pada Bengkel Abadi Jaya Motor.

\section{3) Pengaruh Kualitas Pelayanan dan Lokasi terhadap Kepuasan Pelanggan (Uji F)}

\begin{tabular}{|c|c|c|c|c|c|}
\hline \multicolumn{6}{|c|}{ Tabel 1.19. Hasil Uji F Simultan } \\
\hline Model & $\begin{array}{l}\text { Sum of } \\
\text { Squares }\end{array}$ & Df & $\begin{array}{l}\text { Mean } \\
\text { Square }\end{array}$ & F & \\
\hline 1 Regression & & 2 & 294,801 & 34,613 & \\
\hline Residual & 672,849 & 79 & 8,517 & & \\
\hline Total & 1262,451 & 81 & & & \\
\hline $\begin{array}{l}\text { a. Dependent Var } \\
\text { b. Predictors: (Ca }\end{array}$ & able: Kepuas & & & & \\
\hline Dari & abel $d$ & at & s din & erolel & \\
\hline $\mathrm{F}_{\text {hitung }}$ lebih & besar d & $\operatorname{ari~} \mathrm{I}$ & tabel ata & $\mathrm{u}(34$ & 13 \\
\hline 2,150$)$ deng & n cinni & Gik & si 00 & $\mathrm{Sol}$ & in $\sigma \alpha$. \\
\hline $\mathrm{H}_{\mathrm{o}}$ ditolak & $\operatorname{lan} \mathrm{H}_{1} \mathrm{~d}$ & teri & na, artir & nya te & ar \\
\hline pengaruh & ositif & & signifi & & \\
\hline multan & ara & & $p t$ & & \\
\hline IOKasI & ap & & & & \\
\hline ngl & i Ja & & & & \\
\hline
\end{tabular}

\section{SIMPULAN}

\section{Kesimpulan}

Dari hasil analisis dan pembahasan dapat disimpulkan:

1. Kualitas pelayanan berpengaruh positif dan signifikan terhadap keputusan pembelian dengan konstribusi sebesar 26,2\%. Hal ini menunjukkan bahwa kualitas pelayanan yang tinggi akan meningkatkan kepuasan pelanggan. Hasil uji t diperoleh $t_{\text {hitung }}(5,334)>t_{\text {tabel }}$ $(1,663)$, dengan signifikansi o,ooo.

2. Lokasi berpengaruh positif dan signifikan terhadap kepuasan pelanggan dengan konstribusi sebesar 41,9\%. Hal ini menunjukkan bahwa lokasi akan meningkatkan keputusan pembelian. Hasil uji $t$ diperoleh $t_{\text {hitung }}(7.602)>t_{\text {tabel }}$ (1,663) dengan probability 0,00o. 
3. Persamaan regresi berganda diperoleh $Y$ $=14,980+0,230 X_{1}+0,473 X_{2}$. Semakin tinggi kualitas pelayanan dan lokasi maka akan meningkatkan kepuasan pelanggan dengan kontribusi sebesar 46,7\% sedangkan sisanya sebesar 53,3\% dipengaruhi faktor lain. Hasil uji statistik diperoleh $F_{\text {hitung }}(34,613)>F_{\text {tabel }}$ $(2,150)$ dengan probability 0,000 . Artinya terdapat pengaruh positif dan signifikan secara simultan antara kualitas pelayanan dan lokasi terhadap kepuasan pelanggan.

\section{Saran}

1. Dalam meningkatkan kualitas pelayanan maka perusahaan perlu meningkatkan kualitas pelayanan salah satunya dengan cara menerapkan sistem $3 \mathrm{~S}$ (senyum, salam dan sapa) bagi setiap karyawan.

2. Perusahaan perlu memberikan kenyamanan bagi masyarakat terkait lokasi. Salah satunya dengan cara memberikan fasilitas tempat parkir yang dekat dengan lokasi bengkel, sehingga memberikan rasa aman bagi masyarakat yang menggunakan jasa yang diberikan.

3. Perusahaan hendaknya dapat memberikan kenyamanan bagi masyarakat dengan cara memberikan barangbarang yang berkualitas untuk kenyamanan masyarakat dalam melakukan aktivitas dengan kendaraan roda dua (motor), sehingga memberikan rasa aman bagi masyarakat yang menggunakan jasa Bengkel Abadi Jaya Motor.

\section{DAFTAR PUSTAKA}

Alma, Buchari. "Manajemen Pemasaran \& Pemasaran Jasa”. Bandung. Edisi Revisi. Alfabeta. 2005.

Arikunto, S. "Prosedur Penelitian, Suatu Pendekatan Praktek". Penerbit Rineka Cipta Bungin, Jakarta, 2010.

Daud, Denny. Promosi Dan Kualitas Layanan Terhadap Keputusan Pembelian Pada PT. Bess Finance Manado. Manajemen. Fakultas Ekonomi Dan Bisnis.Universitas Sam Ratulangi Manado. 2013.

Dwintha, Tiyani. Analisis Bauran Promosi Dalam Meningkatkan Volume Penjualan Mobil Daihatsu Pada PT. Jujur Jaya Sakti Makassar.

Manajemen. Fakultas Ekonomi Dan Bisnis. Universitas Hasanudin Makasar. 2012.

George, Terry. Dasar-Dasar Manajemen. Cetakan Kesebelas. PT. Bumi Aksara. Jakarta. 2010.

Handoko, T. Hani. Manajemen Sumber Daya Manusia. Yogyakarta BPFE. 2012.

Hasibuan, SP, "Dasar-dasar Perbankan", Haji Masagung, Jakarta, 2012.

Kotler, Philip \& Gary Armstrong. Principles of Marketing. Eleventh Edition, Pearson Prentice Hall, New Jersey. 2006. 
Kotler, Philip dan Kevin L. Keller. Manajemen Pemasaran. Jakarta. Penerbit Indeks. 2007.

Kotler, Philip and Kevin Lane Keller. Marketing Management 13. New Jersey. Pearson Prentice Hall, Inc. 2012.

Mandasari, Ii. "Pengaruh Promosi dan Kualitas Pelayanan Terhadap Keputusan Nasabah Untuk Menabung Pada BRI Syariah cabang Cirebon”. Manajamen. Institut Agama Islam Negri (IAIN) Syekh Nurjati. Cirebon. 2015.

Noor, Juliansyah. "Metodelogi Penelitian". Penerbit Prenhalindo. Jakarta. 2000.

Peter, J.P. \& Olson, J.C. Consumer Behaviour \& Marketing Strategy, New York: McGraw-Hill Companies, Inc. Seventh Edition. 2005.

Rambat, Lupiyoadi. Manajemen

Pemasaran Jasa. Salemba Empat. Jakarta. 2008.

Saladin, Djaslim, "Manajemen

Pemasaran”, Linda Karya, Bandung, 2012.

Sarwono, Jonathan, "Metode Penelitian

Kuantitatif Dan Kualitatif", Graha Ilmu, Yogyakarta, 2012

Setiadi, Nugroho. Perilaku Konsumen. Jakarta. Cetakan Keempat. Penerbit Kencana Prenada Media Group. 2010. Simamora, Bilson, "Panduan Riset Dan Perilaku Konsumen", PT. Gramedia Pustaka Utama, Jakarta, 2013.

Singgih Santoso, "SPSS Statistik

Parametik” Cetakan Kedua, PT. Elek
Media Sugiyono, "Metode Penelitian Kuantitatif Kualitatif dan $R$ \& $D$, Penerbit CV. Alfabeta, Bandung, 2012. Sugiyono, "Metode Penelitian Kuantitatif Kualitatif dan $R \& D$ ”, Penerbit CV. Alfabeta, Bandung, 2014.

Supranto, Pengukuran Tingkat Kepuasan Pelanggan. Jakarta. Cetakan Ketiga. Penerbit Rineka. 2006.

Swasta, Basu dan Irawan. "Manajemen Pemasaran Modern”. Liberty. Yogyakarta. 1990.

Swastha, Bashu dan T. Handoko, "Manajemen Pemasaran Moderen", BPFE, Yogyakarta, 2010.

Syofian Siregar, "Statistika Deskriptif Untuk Penelitian”, PT Raja Grafindo Persada, Jakarta, 2010.

Tjiptono, Fandy. Strategi Pemasaran. Edisi 3. Andi Offset. Yogyakarta. 2008.

Tjiptono, Fandy. Strategi Pemasaran Jasa. CV. Andi. Yogyakarta. 2009.

Tjiptono, Fandy \& Gregorius Chandra. Pemasaran Strategik. Yogyakarta. Edisi Kedua. Penerbit Andi. 2012.

Tjiptono, Fandy dan Gregorius Chandra, "Serivce Quality and Satisfiation", Edisi tiga, Andi, Jakarta, 2012.

Utama, Rai. "Pengaruh Kualitas Pelaynan dan Promosi Terhadap Keputusan Konsumen Dalam Pmbelian Produk Pada Salon Kecantikan Mutiara Sading Mengwi”.

Manajamen. Fakultas Ekonomika. Universitas Dhyana Pura. Bandung. 2016 
Rocket."Definisi Manajemen”. sumber:

http://rocketmanajemen.com/2odefi

nisimanajemen-menurut-para-ahli/.

Diakses Tanggal 25 Januari 2018 Jam

20.36 WIB 